\title{
Antimicrobial resistance evaluation of bacteria isolated from infections in small animals in the Umuarama region, Paraná ${ }^{1}$
}

\author{
Marilia M. Souza², Jéssica T. Bordin ${ }^{3}$, Ana Cláudia L. Pavan³ ${ }^{3}$ Raquel G.A. Rodrigues², \\ Ricardo A.P. Sfaciotte ${ }^{4}$, Vanessa K.C. Vignoto ${ }^{5}$, Marcos Ferrante ${ }^{6}$ (D) \\ and Sheila R. Wosiacki ${ }^{* *}$ (D)
}

\begin{abstract}
Souza M.M., Bordin J.T., Pavan A.C.L., Rodrigues R.G.A., Sfaciotte R.A.P., Vignoto V.K.C., Ferrante M. \& Wosiacki S.R. 2020. Antimicrobial resistance evaluation of bacteria isolated from infections in small animals in the Umuarama region, Paraná. Pesquisa Veterinária Brasileira 40(10):804-813. Departamento de Medicina Veterinária, Universidade Estadual de Maringá, Estrada da Paca s/n, Jardim São Cristóvão, Umuarama, PR 87507-190, Brazil. E-mail: srwosiacki@uem.br

Bacterial resistance is shown to be an inevitable side effect due to the excessive use of antibiotics, becoming a significant concern worldwide. Knowledge of regional bacterial resistance profiles enables the development of site-specific infection control practices, making conscious and moderate use of commercially available antibiotics. The aim of this study was the retrospective evaluation of the antimicrobial resistance profile of bacteria isolated from companion animal infections in the region of Umuarama/PR, from 2013 to 2017. This research was performed by analyzing the database belonging to the "Laboratório de Microbiologia Animal" at the "Universidade Estadual de Maringá" (UEM). Staphylococcus spp. represented $45.53 \%$ of the bacteria isolated from clinical infections in small animals in the period and place evaluated, followed by enterobacteria (34.04\%), non-fermenting Gram-negative bacilli (NFGNB, 11.06\%) and Streptococcus/Enterococcus (9.36\%). A high number of antimicrobial resistance to antibiotics used in veterinary medicine was found. The lowest resistances associated with the best impact factor values were found for aminoglycosides, especially amikacin, chloramphenicol, and fluoroquinolones (norfloxacin and ciprofloxacin). Intermediate results were found for sulbactam-associated ampicillin, ceftriaxone, amoxicillin-clavulanic acid, and enrofloxacin. According to the number of resistant antimicrobial drugs, $64.26 \%$ $(151 / 235)$ of the isolates were classified as multidrug-resistant, being $15.32 \%$ extensively resistant. Considering the resistance to antimicrobial classes, $68.94 \%(162 / 235)$ of the isolates were classified as multiresistant, being $19.15 \%$ extensively resistant. No bacterial strains were characterized as pan-resistant, but ten bacteria were resistant to all classes tested, with isolated susceptibility to certain drugs. Through the evaluation of resistance profiles found in the period and place studied and relevant literature, it is clear that there is a growing increase in the number of multiresistant bacteria among domestic animals which characterizes a serious risk to public health. The therapeutic arsenal is becoming increasingly diminished, and there is more difficulty in empirical drug selection, making antimicrobial susceptibility testing essential for more specific selection in antimicrobial therapy. Educational
\end{abstract}

${ }^{1}$ Received on August 9, 2019.

Accepted for publication on July 11, 2020.

${ }^{2}$ Graduate Program in Sustainable Production and Animal Health, Universidade Estadual de Maringá (UEM), Estrada da Paca s/n, Bairro São Cristóvão, Umuarama, PR 87507-190, Brazil.

${ }^{3}$ Residence in Infectious and Parasitic Diseases, Universidade Estadual de Maringá (UEM), Estrada da Paca s/n, Bairro São Cristóvão, Umuarama, PR 87507-190, Brazil.

\footnotetext{
${ }^{4}$ Centro de Ciências Agroveterinárias, Universidade do Estado de Santa Catarina (UDESC), Av. Luiz de Camões 2090, Conta Dinheiro, Lages, SC 88520-000, Brazil.

${ }^{5}$ Departamento de Medicina Veterinária, Universidade Estadual de Maringá (UEM), Estrada da Paca s/n, Bairro São Cristóvão, Umuarama, PR 87507190, Brazil. *Corresponding author: srwosiacki@uem.br

${ }^{6}$ Departamento de Medicina Veterinária, Universidade Federal de Lavras (UFLA), Campus Universitário, Cx. Postal 3037, Lavras, MG 37200-000, Brazil.
} 
measures on the conscious use of antibiotics, infection control, and prevention of local specific zoonoses need to be instituted for the knowledge of health professionals and general access of the population.

INDEX TERMS: Antimicrobial resistance, bacteria, infection, small animals, Brazil, antibiotics, multiresistance, dogs, cats.

\section{RESUMO.- [Avaliação da resistência antimicrobiana de bactérias isoladas de infecções em pequenos animais na região de Umuarama, Paraná.] A resistência bacteriana,} mostra-se como um efeito colateral inevitável pelo excessivo uso de antibióticos, tornando-se alvo de grande preocupação mundial. 0 conhecimento dos perfis de resistência bacteriana regionais possibilita o desenvolvimento de práticas de controle de infecções específicas para cada localidade, fazendo uso consciente e moderado dos antibióticos disponíveis no mercado. 0 objetivo deste estudo foi a avaliação retrospectiva do perfil de resistência antimicrobiana de bactérias isoladas de infecções de animais de companhia na região de Umuarama/PR, no período de 2013 a 2017. Esta pesquisa foi realizada por meio da análise do banco de dados pertencente ao Laboratório de Microbiologia Animal da Universidade Estadual de Maringá (UEM). Os Staphylococcus spp. representaram 45,53\% das bactérias isoladas de infecções clínicas em pequenos animais no período e local avaliado, seguido por enterobactérias (34,04\%), bacilos Gram-negativos não fermentados (BGNNF, $11,06 \%$ ) e Streptococcus/Enterococcus (9,36\%). Um número elevado de resistência antimicrobiana frente aos antibióticos utilizados na medicina veterinária foi encontrado. As menores resistências associadas aos melhores valores do fator de impacto foram encontrados para aminoglicosídeos, em especial amicacina, cloranfenicol, fluoroquinolonas (norfloxacina e ciprofloxacina). Já resultados intermediários foram encontrados para ampicilina associada a sulbactam, ceftriaxona, amoxacilina com ácido clavulônico e enrofloxacina. Conforme o número de drogas antimicrobianas resistentes, foram classificados como multirresistentes 64,26\% (151/235) dos isolados, sendo $15.32 \%$ extensivamente resistentes. Já considerando a resistência a classes de antimicrobianos, 68,94\% (162/235) dos isolados foram classificados como multirresistentes, sendo 19.15\% extensivamente resistentes. Nenhum isolado bacteriano foi caracterizado como pan-resistente, porém 10 bactérias foram resistentes a todas as classes testadas, com susceptibilidade isolada a determinadas drogas. Por meio da avaliação dos perfis de resistência encontrados no período e local estudados e de literatura pertinente, percebe-se que há um aumento crescente no número de bactérias multirresistentes entre os animais domésticos o que caracteriza um grave risco à saúde pública. 0 arsenal terapêutico está se tornando cada vez mais diminuto e há mais dificuldade na seleção empírica de drogas, tornando essencial a realização de testes de susceptibilidade antimicrobiana para uma seleção mais específica na terapêutica antimicrobiana. Medidas educativas sobre o uso consciente dos antibióticos, controle de infecções e prevenção de zoonoses específicas para as localidades precisam ser instituídas para conhecimento dos profissionais do setor da saúde e acesso geral da população.

TERMOS DE INDEXAÇÃO: Resistência antimicrobiana, bactérias, infecção, pequenos animais, Brazil, antibióticos, multirresistência, cães, gatos.

\section{INTRODUCTION}

Antimicrobials include any natural substance of semisynthetic or synthetic origin that kills or inhibits the growth of a microorganism, causing little or no damage to the host. Among these, the most widely used are antibiotics that were defined by Giguère (2013) as a low molecular weight substance produced by a microorganism that inhibits or kills other organisms at low concentrations. Since its discovery in 1928, when Alexandre Flemming noted that staphylococci colonies were lysed on a Penicillium-contaminated plaque (Prescot 2013), they are widely used for the treatment or prevention of bacterial infections and are among the most important advances in modern medicine (Murphy et al. 2012).

As soon as penicillin was discovered, the presence of in vitro resistance was observed and it was said, in the early years of its application, that there was a need to be aware of the precautions to be taken when administering the drug due to possible undesirable reactions and even of antibiotic resistance (Pereira \& Pita 2005).

Although numerous studies have provided substantial evidence of the spread of multi-resistant bacteria from animals to humans, current research indicates that humans can also transmit animal-resistant pathogens in a reverse zoonotic event called zooanthroponosis (Messenger et al. 2014). Pathogens acquired in the hospital environment by owners, for example, can be transmitted directly to the animal or indirectly through the domestic environment, becoming a critical route of transmission between them (Fernandes et al. 2018).

Resistant pathogen transfer rates at the human-animal interface as well as antibiotic resistance were increased in both companion animals (Aidara-Kane 2012) and humans. This increase was accompanied by the more frequent use of these broad-spectrum drugs in the treatment of patients without real certainty of this need as bacterial agent identification, and susceptibility tests are not performed most of the time (Guardabassi et al. 2010).

Antimicrobial resistance is defined as the condition in which a microorganism can survive when exposed to an antimicrobial to which it was initially susceptible (Barie 2012, WHO 2019) or organisms capable of multiplying in the presence of therapeutic or higher antimicrobial concentrations (Sfaciotte et al.2017). It is considered a complex phenomenon, especially in veterinary medicine, due to the number of species and the diversity of environments in which animals are reared, the differences in the bacteria involved, the range of pathogenicity mechanisms and the intricate epidemiology (Acar et al. 2012). Antimicrobial resistance is an inevitable side effect due to the excessive use of these drugs (Guardabassi et al. 2010) and is a subject of intense worldwide concern (Ventola 2015).

Antimicrobial susceptibility testing is considered to be one of the most important factors governing drug selection for veterinary clinical use and is used in the elaboration of local therapeutic guides (ANVISA 2017). Joseph \& Rodvold (2008) described the "4 D's of Ideal Antimicrobial Therapy": right Drug, right Dose, De-escalated to pathogen-directed therapy, and right Duration of therapy. De-escalating is referred to by Molina et al. (2012) as an intervention aimed at improving the 
use of antimicrobials and implying their discontinuation when there is no infection or restricting the spectrum of antimicrobial coverage according to clinical response and bacterial cultures.

The aim of this study was to retrospectively evaluate the antimicrobial resistance profile found in bacteria isolated from infections in small animals in the Umuarama/PR region.

\section{MATERIALS AND METHODS}

This research was conducted through the analysis of the database belonging to the "Laboratório de Microbiologia Animal" of the "Universidade Estadual de Maringá" (UEM), located at the "Campus Regional de Umuarama” (CAU), Fazenda, from 2013 to 2017.

The Laboratory database refers to the exam files containing animal identification items (name, ID number, species, race, sex, age, material collected and clinical diagnosis), identification of the bacteria (s) isolated (s) and results of the diameter of the bacterial growth inhibition halos obtained by disc diffusion or antibiogram technique.

The information obtained from the exam files was inserted into spreadsheets using Excel software, where it was separated by year of isolation, bacterial type, and place of infection. A total of 32 antibiotics in 11 classes were used. The interpretation of antimicrobial resistance/susceptibility was performed by CLSI $(2008,2013,2018)$ and BrCAST (2019) standards, as shown in Table 1.

Following the guidance of BrCAST (2019), members of the old family Enterobacteriaceae were referred to as members of the new order Enterobacterales. The order Enterobacterales currently includes the families (Adeolu et al. 2016). Enterobacteriaceae, Erwiniaceae, Pectobacteriaceae, Yersiniaceae, Hafniaceae, Morganellaceae, and Budviciaceae

Table 1. Antimicrobial susceptibility interpretation standard, in millimeters of growth inhibition halos, for bacteria of animal origin

\begin{tabular}{|c|c|c|c|c|c|c|c|}
\hline & & $\begin{array}{l}\text { Staphylococcus } \\
\text { spp. }\end{array}$ & $\begin{array}{c}\text { Enterococcus } \\
\text { spp. }\end{array}$ & $\begin{array}{l}\text { Streptococcus } \\
\text { spp. }\end{array}$ & Enterobacterales & $\begin{array}{l}\text { Pseudomonas } \\
\text { spp. }\end{array}$ & $\begin{array}{c}\text { Acinetobacter } \\
\text { baumannii }\end{array}$ \\
\hline Penicillin G & $10 \mathrm{U}$ & $\geq 29^{a}$ & $\geq 15^{\mathrm{a}}$ & $\geq 24^{\mathrm{a}}$ & - & $-a$ & \\
\hline Ampicillin & $10 \mu \mathrm{g}$ & & $\geq 17^{\mathrm{a}}$ & $\geq 24^{\mathrm{a}}$ & $\geq 17^{\mathrm{a}}$ & $-\mathrm{a}$ & \\
\hline Amoxacillin & $10 \mu \mathrm{g}$ & & & $\mathrm{amp}^{\mathrm{a}}$ & $\mathrm{amp}^{\mathrm{a}}$ & $-a$ & \\
\hline $\begin{array}{l}\text { Ampicillin + } \\
\text { sulbactam }\end{array}$ & $20 \mu \mathrm{g}$ & pen e oxa ${ }^{a}$ & pen e oxa ${ }^{a}$ & $-\mathrm{a}$ & $\geq 14^{b}$ & $-\mathrm{a}$ & \\
\hline $\begin{array}{l}\text { Amoxacillin + } \\
\text { clavulonate }\end{array}$ & $30 \mu \mathrm{g}$ & & & $-{ }^{a}$ & $\geq 19^{a}$ & $-{ }^{a}$ & \\
\hline Oxacillin & $1 \mu \mathrm{g}$ & $\geq 18^{\mathrm{a}}$ & $-{ }^{a}$ & $\geq 20$ & $-a$ & $-{ }^{a}$ & \\
\hline Cefoxitin & $30 \mu \mathrm{g}$ & $\geq 22^{\mathrm{a}}$ & $\mathrm{IR}^{\mathrm{a}}$ & & $\geq 19^{\mathrm{b}}$ & $-a$ & \\
\hline $\begin{array}{l}\text { Cephalothin/ } \\
\text { Cephalexin }\end{array}$ & $30 \mu \mathrm{g}$ & & $\mathrm{IR}^{\mathrm{a}}$ & & $\geq 14^{\mathrm{b}}$ & & \\
\hline Ceftazidime & $30 \mu \mathrm{g}$ & pen e oxa ${ }^{a}$ & $\mathrm{IR}^{\mathrm{a}}$ & & $\geq 22^{b}$ & $\geq 17^{\mathrm{b}}$ & \\
\hline Cefotaxime & $30 \mu \mathrm{g}$ & & $\mathrm{IR}^{\mathrm{a}}$ & & & $\geq 23^{c}$ & \\
\hline Ceftriaxone & $30 \mu \mathrm{g}$ & nen e oxa a & $\mathrm{IR}^{\mathrm{a}}$ & $\geq 24^{\mathrm{a}}$ & $\geq 25^{\mathrm{a}}$ & $\geq 21^{c}$ & \\
\hline Cefepime & $30 \mu \mathrm{g}$ & pen e oxa & $\mathrm{IR}^{\mathrm{a}}$ & $\geq 24^{\mathrm{a}}$ & $\geq 27^{b}$ & $\geq 21^{b}$ & \\
\hline Aztreonam & $30 \mu \mathrm{g}$ & $\mathrm{IR}^{\mathrm{a}, \mathrm{b}}$ & $\mathrm{IR}^{\mathrm{a}}$ & & $\geq 26^{b}$ & $\geq 16^{\mathrm{b}}$ & \\
\hline Meropenem & $10 \mu \mathrm{g}$ & pen e oxa ${ }^{a}$ & $-\mathrm{a}$ & & $\geq 22^{a}$ & $\geq 24^{b}$ & $\geq 21^{b}$ \\
\hline Imipenem & $10 \mu \mathrm{g}$ & pen e oxa $^{d}$ & $\geq 21^{b}$ & & $\geq 23^{\mathrm{a}}$ & $\geq 19^{\mathrm{a}}$ & $\geq 23^{b}$ \\
\hline Vancomycin & $30 \mu \mathrm{g}$ & $\geq 18^{d}$ & $\geq 17^{\mathrm{a}}$ & $\geq 17^{\mathrm{a}}$ & $\mathrm{IR}^{\mathrm{a}}$ & & \\
\hline Teicoplamine & $30 \mu \mathrm{g}$ & $\operatorname{van}^{a}$ & $-{ }^{a} \geq 16^{b}$ & $\geq 17^{\mathrm{b}}$ & $\mathrm{IR}^{\mathrm{a}}$ & & \\
\hline Linezolid & $30 \mu \mathrm{g}$ & $\geq 21^{b}$ & $-{ }^{a} \geq 19^{b}$ & $\geq 19^{\mathrm{a}}$ & $\mathrm{IR}^{\mathrm{a}}$ & & \\
\hline Amikacin & $30 \mu \mathrm{g}$ & $\geq 18^{\mathrm{a}}$ & $\mathrm{IR}^{\mathrm{a}}$ & $-{ }^{a}$ & $\geq 17^{\mathrm{a}}$ & $\geq 17^{\mathrm{a}}$ & $\geq 19^{b}$ \\
\hline Gentamicin & $10 \mu \mathrm{g}$ & $\geq 15^{a}$ & $\mathrm{IR}^{\mathrm{a}} \geq 8^{\mathrm{b}}$ & $-a$ & $\geq 16^{\mathrm{a}}$ & $\geq 16^{\mathrm{a}}$ & $\geq 17^{\mathrm{b}}$ \\
\hline Streptomycin & $10 \mu \mathrm{g}$ & - & $\mathrm{IR}^{\mathrm{a}} \geq 14^{\mathrm{b}}$ & $-a$ & $\geq 15^{\mathrm{a}}$ & & $\geq 17^{\mathrm{b}}$ \\
\hline Tobramycin & $10 \mu \mathrm{g}$ & $\geq 18^{b}$ & $\mathrm{IR}^{\mathrm{a}}$ & $-{ }^{a}$ & $\geq 17^{\mathrm{a}}$ & $\geq 16^{\mathrm{b}}$ & \\
\hline Erythromycin & $15 \mu \mathrm{g}$ & $\geq 23^{\mathrm{a}}$ & $\geq 23^{\mathrm{a}}$ & $\geq 21^{\mathrm{a}}$ & $\mathrm{IR}^{\mathrm{a}}$ & & \\
\hline Azithromyx & $15 \mu \mathrm{g}$ & & & $\geq 18^{\mathrm{a}}$ & $\mathrm{IR}^{\mathrm{a}}$ & & \\
\hline Clindamycin & $2 \mu \mathrm{g}$ & $\geq 21^{\mathrm{a}}$ & $\mathrm{IR}^{\mathrm{a}}$ & $\geq 17^{\mathrm{a}}$ & $\mathrm{IR}^{\mathrm{a}}$ & & \\
\hline Rifampicin & $5 \mu \mathrm{g}$ & $\geq 20^{\mathrm{a}}$ & $\geq 20^{\mathrm{a}}$ & $\geq 21^{\mathrm{a}}$ & $-a$ & & \\
\hline Chloramphenicol & $30 \mu \mathrm{g}$ & $\geq 18^{a}$ & $\geq 18^{a}$ & $\geq 19^{a}$ & $\geq 18^{a}$ & & \\
\hline Tetracycline & $30 \mu \mathrm{g}$ & $\geq 23^{\mathrm{a}}$ & $\geq 19^{\mathrm{a}}$ & $\geq 23^{\mathrm{a}}$ & $\geq 15^{\mathrm{a}}$ & & \\
\hline Doxycycline & $30 \mu \mathrm{g}$ & $\geq 25^{a}$ & $\geq 16^{\mathrm{a}}$ & $\geq 28^{a}$ & $\geq 14^{\mathrm{a}}$ & & \\
\hline $\begin{array}{l}\text { Sulfamethoxazole + } \\
\text { trimethoprim }\end{array}$ & $23.7 / 1.25 \mu \mathrm{g}$ & $\geq 16^{\mathrm{a}}$ & $\mathrm{IR}^{\mathrm{a}}$ & $\geq 19^{\mathrm{a}}$ & $\geq 16^{\mathrm{a}}$ & & \\
\hline Enrofloxacin & $10 \mu \mathrm{g}$ & $\geq 23^{\mathrm{a}}$ & $-{ }^{a}$ & $\geq 23^{\mathrm{a}}$ & $\geq 23^{\mathrm{a}}$ & $\geq 23^{\mathrm{a}}$ & \\
\hline Norfloxacin & $10 \mu \mathrm{g}$ & $\geq 17^{\mathrm{b}}$ & $\geq 12^{\mathrm{a}}$ & $\geq 12^{\mathrm{a}}$ & $\geq 22^{\mathrm{a}}$ & $\geq 17^{c}$ & \\
\hline Ciprofloxacin & $5 \mu \mathrm{g}$ & $\geq 21^{b}$ & $-\mathrm{a}$ & & $-{ }^{a} \geq 26^{b}$ & $\geq 26^{b}$ & $\geq 21^{\mathrm{b}}$ \\
\hline Levofloxacin & $5 \mu \mathrm{g}$ & $\geq 22^{\mathrm{b}}$ & $-a$ & $\geq 17^{\mathrm{a}}$ & $-{ }^{a} \geq 23^{b}$ & $\geq 22^{\mathrm{b}}$ & $\geq 23^{\mathrm{b}}$ \\
\hline
\end{tabular}


The categories were organized into:

I) Gram-positive bacteria: Staphylococcus spp., Enterococcus spp., Streptococcus spp., Enterococcus/Streptococcus (when it was not possible to differentiate gender);

II) Gram-negative bacteria: order Enterobacterales and NFGNB (non-fermenting Gram-negative bacilli). Clinically significant NFGNB associated with severe nosocomial infections such as Pseudomonas spp. and Acinetobacter baumannii were reported separately from the other NFGNB, which were included in the "other" category.

Absolute and relative frequencies of antimicrobial resistance were determined using descriptive statistical analysis. The graphics were made by Excel software.

The impact factor of each antimicrobial drug used to help choose empirical antimicrobial therapy was calculated according to Rampacci et al. (2018) and referred to the results of the prevalence study and antimicrobial susceptibility test (antibiogram) with their frequency expressed as a percentage, according to the formula:

$\mathrm{F}=\left[\frac{\% \mathrm{P}\left({ }_{S t}\right) \times \% \mathrm{~S}\left({ }_{S t}\right)}{100}\right]+\left[\frac{\% \mathrm{P}\left({ }_{\mathrm{E} / \mathrm{S}}\right) \times \% \mathrm{~S}\left({ }_{\mathrm{E} / \mathrm{S}}\right)}{100}\right]+\left[\frac{\% \mathrm{P}\left({ }_{\mathrm{E}}\right) \times \% \mathrm{~S}\left({ }_{\mathrm{E}}\right)}{100}\right]+\left[\frac{\% \mathrm{P}\left({ }_{\mathrm{N}}\right) \times \% \mathrm{~S}\left({ }_{\mathrm{S}}\right)}{100}\right]$

Where $\mathrm{F}=$ impact factor of the evaluated antibiotic, $\% \mathrm{P}=$ prevalence of bacteria isolated from each bacterial group, \% $\mathrm{S}$ = percentage of antibiotic susceptibility of each bacterial group, $\left(\mathrm{S}_{\mathrm{St}}\right)=$ Staphylococcus, $\left(\mathrm{C}_{\mathrm{E} / \mathrm{S}}\right)=$ Enterococcus $/$ Streptococcus, $\left(\mathrm{E}_{\mathrm{E}}\right)=$ Enterobacteriales, $\left(_{N}\right.$ ) = NFGNB.

The Multiple Antibiotic Resistance Indexing (MAR), according to Krumperman (1983), was calculated by the number of antibiotics to which the isolate had resistance (including intermediate resistance) divided by the total number of antibiotics tested. Bacteria with an index equal to or greater than 0.2 (20\% of the tested antibiotics) were considered multidrug-resistant.

Multidrug-Resistant Bacteria (MDR), according to Magiorakos et al. (2012), were detected by the calculation, through an index, considering the number of resistant classes in relation to the total number of tested classes. The class was considered resistant when one or more drugs were resistant. Values equal to or greater than 0.3 were considered multidrug-resistant, values equal to or greater than 0.8 as extensively drug-resistant, and values of 1.0 with resistance to all drugs tested were considered pandrug-resistant.

\section{RESULTS AND DISCUSSION}

During the study period, 235 bacterial strains collected from infections in small animals were isolated, 207 from dogs and 28 from cats. The records were evaluated regardless of age and gender, and all animals were from the Umuarama region and surrounding areas in the state of Paraná, Brazil.

Given the analysis of the data obtained, the most common microorganisms $(54.89 \%, 129 / 235)$ in dogs and cats were Gram-positive bacteria. Of these, 82.17\% (106/129) were identified as Staphylococcus spp., representing $45.10 \%$ of the total bacterial isolates studied (for further analysis Micrococcus spp. was included with Staphylococcus spp. for similarity). The second most prevalent genus of Gram-positive bacteria was Enterococcus (8.53\%,11/129), followed by Streptococcus $(4.65 \%, 6 / 129)$. Five isolates were not differentiated between Enterococcus and Streptococcus genera. Of the 106 (45.1\%) Gram-negative bacteria, Enterobacterales were identified in $75.47 \%(80 / 106)$ of the isolates, their largest representative was Escherichia coli identified in $13.75 \%(11 / 80)$, while NFGNB were identified in 26 isolates, of which $73.08 \%(19 / 26)$ comprised Pseudomonas spp. Despite the low frequency, the identification of Acinetobacter baumannii and Burkholderia pseudomallei (Table 2) is noteworthy.

The highest prevalence of Gram-positive bacteria, especially Staphylococcus spp., is found in several studies (Pereira et al. 2009, Ishii et al. 2011, Sfaciotte et al. 2014, Kohl et al. 2016) of infections in dogs and cats. Sfaciotte et al. (2014) and Kohl et al. (2016) also identified Escherichia coli as the second most prevalent bacteria. Ishii et al. (2011) detected a high prevalence of Pseudomonas spp. in samples from wounds, followed by Escherichia coli. The prevalence of other bacteria was similar in studies conducted by Ishii et al. (2011), Kohl et al. (2016) and in the present work. Ishii et al. (2011) was also detected Acinetobacter spp.

Most cases of infections evaluated occurred in the integumentary system (98/235, 41.70\%); followed by infections in the sensory system $(83 / 235,35.32 \%)$, divided into otological infections $(69 / 235,29.36 \%)$, ophthalmic and nasal infections $(7 / 235$, $2.98 \%$ each); in the urinary system $(32 / 235 ; 13.62 \%)$; in the female reproductive system collected from vaginal secretions $(10 / 235,4.26 \%)$; and other systems, with body fluids by CSF collection or abdominal aspiration from peritonitis $(4 / 235$, $1.70 \%)$. The origin of the materials was not identified in the eight-sample examination sheet (3.40\%) (Table 3).

With a higher frequency of clinical infections, and more straightforward diagnosis and collection, samples of integumentary infections, urinary and otological infections, are often more sent to microbiology laboratories by clinicians, as also reported by Pereira et al. (2009), Ishii et al. (2011) and Kohl et al. (2016).

A high number of antimicrobial resistance to antibiotics used in veterinary medicine was found (Fig.1). In Staphylococcus spp. resistance/susceptibility to beta-lactam drugs is predicted by penicillin, oxacillin, and cefoxitin (CLSI 2018, BrCAST 2019). Penicillin resistance predicts resistance to penicillins and aminopenicillins, and these strains are considered susceptible to the association of aminopenicillins with beta-lactamase inhibitors (clavulanic acid and sulbactam). Oxacillin/cefoxitin resistance predicts resistance to all beta-lactam drugs, including penicillins, aminopenicillins, whether or not associated with inhibitors, cephalosporins, except the 5th generation, untested, and carbapenems. In this study, 24.30\% (26/107) of Staphylococcus spp. were susceptible to all beta-lactams drugs, $37.38 \%$ (40/107) were resistant to penicillins and aminopenicillins but sensitive to associations with betalactamase inhibitors, cephalosporins, and carbapenem, and $38.32 \%$ (41/107) were resistant to all beta-lactams.

Staphylococcus spp. resistant to oxacillin/cefoxitin are reported as methicillin-resistant Staphylococcus spp. (MRS), often being studied for their great clinical and epidemiological importance. These strains are often associated with resistance to several other antimicrobial drugs (Bardiau et al. 2013, Haenni et al. 2014).

Bardiau et al. (2013) detected high resistance to penicillin, gentamicin, amikacin, erythromycin, tetracycline, ciprofloxacin, clindamycin, sulfa, and chloramphenicol in methicillin-resistant Staphylococcus pseudintermedius (MRSP) from dogs and cats from Belgium. All isolates were resistant to at least five of the fifteen tested antibiotics. One isolate was resistant to all tested antibiotics.

Haenni et al. (2014) in their study also with canine origin MRSP found high resistance to penicillin, tetracycline, erythromycin, enrofloxacin, amikacin, tobramycin and 
gentamicin, only chloramphenicol had a lower resistance (22\%). In MSSP strains, low resistance was found for all drugs, especially enrofloxacin (9.4\%), tobramycin and gentamicin (5.4\% each).
The Enterobacteriales order has intrinsic resistance to penicillin, but aminopenicillins, considered broad-spectrum penicillins, also show adequate Gram-negative action. Resistance to these drugs was found in $68.75 \%$ (55/80) of

Table 2. Identification of isolated bacteria in small animal infections in the Umuarama region, Paraná

\begin{tabular}{|c|c|c|c|c|}
\hline \multicolumn{3}{|c|}{ Identification } & \multirow{2}{*}{$\begin{array}{c}\mathrm{n} \\
106\end{array}$} & \multirow{2}{*}{$\begin{array}{c}\% \\
45.10\end{array}$} \\
\hline Gram-positive & & Staphylococcus spp. & & \\
\hline & & Micrococcus spp. & 1 & 0.43 \\
\hline & & Enterococcus spp. & 11 & 4.68 \\
\hline & & Streptococus/Enterococcus & 5 & 2.13 \\
\hline & \multicolumn{2}{|l|}{ Total } & 129 & 54.89 \\
\hline \multirow{30}{*}{ Gram-negative } & & Salmonella spp. & 4 & 1.70 \\
\hline & & Citrobacter spp. & 3 & 1.28 \\
\hline & & Citrobacter braakii & 2 & 0.85 \\
\hline & & Citrobacter freundii & 1 & 0.43 \\
\hline & & Citrobacter youngae & 1 & 0.43 \\
\hline & & Klebsiella oxytoca & 1 & 0.43 \\
\hline & & Klebsiella ozaenae & 1 & 0.43 \\
\hline & & Morganella morganii & 4 & 1.70 \\
\hline & & Enterobacter amnogenus 2 & 2 & 0.85 \\
\hline & & Enterobacter sakazakii & 1 & 0.43 \\
\hline & & Enterobacter cloacae & 2 & 0.85 \\
\hline & & Enterobacter cancerogenus & 3 & 1.28 \\
\hline & & Enterobacter spp. & 1 & 0.43 \\
\hline & & Hafnia alvei & 3 & 1.28 \\
\hline & & Serratia spp. & 2 & 0.85 \\
\hline & & Yersinia spp. & 1 & 0.43 \\
\hline & & Shigela boydii sorogrupo C & 1 & 0.43 \\
\hline & & Leclercia adecarboxylata & 2 & 0.85 \\
\hline & & Ralstonia picketti va2 & 1 & 0.43 \\
\hline & & Kluyvera ascorbata & 1 & 0.43 \\
\hline & & Not identified & 6 & 2.55 \\
\hline & \multicolumn{2}{|l|}{ Total } & 80 & 34.04 \\
\hline & \multirow[t]{7}{*}{ Non-fermenting Gram-negative bacilli } & Pseudomonas aeruginosa & 19 & 8.09 \\
\hline & & Acinetobacter baumannii & 2 & 0.85 \\
\hline & & Burkholderia pseudomallei & 1 & 0.43 \\
\hline & & Ochrobactrum anthropi & 1 & 0.43 \\
\hline & & Chromobacterium violaceum & 1 & 0.43 \\
\hline & & Brevundimonas vesicularis & 1 & 0.43 \\
\hline & & Not identified & 1 & 0.43 \\
\hline & \multirow{2}{*}{\multicolumn{2}{|c|}{ Total }} & 26 & 11.06 \\
\hline TOTAL & & & 235 & $100 \%$ \\
\hline
\end{tabular}


the studied enterobacterial isolates. In the combination of amoxicillin with clavulanic acid, resistance was identified in $52.50 \%(42 / 80)$ of the isolates, whereas in the combination of ampicillin with sulbactam the resistance was only $28.95 \%$ (22/76). Resistance to cephalosporins was detected in $55.70 \%$ (44/79) of enterobacteria for first generation (cephalothin), $48.68 \%$ and $55.00 \%$ for the third generation (ceftriaxone and ceftazidime, respectively), and $56.06 \%$ for fourth generation (cefepime). Carbapenems, hospital drugs indicated for the treatment of severe infections by multiresistant enterobacteria, presented a resistance percentage of $7.50 \%(6 / 80)$ and $18.42 \%(14 / 76)$ for meropenem and imipenem, respectively.

Carvalho et al. (2016), studying E. coli from dog feces in Rio de Janeiro, Brazil, found a resistance percentage of $85.7 \%$ to ampicillin, $35.7 \%$ to amoxicillin with clavulanic acid, $33.3 \%$ to cefalexin, $16.6 \%$ to ceftazidime, $19.4 \%$ to cefotaxime, $21.4 \%$ to ceftriaxone and $9.5 \%$ to cefepime.

Pseudomonas are susceptible only to third and fourth generations of cephalosporins and carbapenems. There were found $66.67 \%$ of resistance to ceftriaxone and cefotaxime and $16.67 \%$ to cefepime. Carbapenem resistance was found in $21.05 \%$ of isolates for meropenem and $16.67 \%$ for imipenem.

Acinetobacter baumannii and Enterococcus spp. are intrinsically resistant to beta-lactams except for carbapenems. Both isolates of Acinetobacter baumannii were susceptible to meropenem, and one was resistant to imipenem, and of the three Enterococcus tested for imipenem, one was resistant.

The second broad class broad-spectrum drug, fluoroquinolones, tested on all bacterial isolates, showed general resistance in the 30-40\% range for the second generation, represented by enrofloxacin (42.56\%), ciprofloxacin (36.45\%) and norfloxacin (32.59\%). The third generation represented by levofloxacin presented resistance in $29.71 \%$ of the isolates tested. Resistance values were similar between Staphylococcus spp. and enterobacteria, in pseudomonas the resistance to enrofloxacin was $40 \%$ while the other fluoroquinolones had resistance in 26 and 29\% in the isolates. The two Acinetobacter isolates were resistant to ciprofloxacin and levofloxacin, as well as all Streptococcus spp. Fifty percent of Enterococcus spp. were resistant to norfloxacin.

Stefanetti etal. (2017) detected resistance to fluoroquinolones in $76 \%$ of isolates to enrofloxacin; Silva et al. (2014) by $20.1 \%$ for enrofloxacin and $18.8 \%$ for ciprofloxacin, representing $22.3 \%$ of fluoroquinolone-resistant bacterial isolates; Ishii et al. (2011) found resistance to enrofloxacin in 53.8\% of isolates and norfloxacin in 41.3\%. Scherer et al. (2018) detected 38.6\% of resistance to enrofloxacin; Kohl et al. (2016) detected 30\% of resistance to enrofloxacin in Gram-negative bacteria and 13.33\% in Gram-positive bacteria; and Carvalho et al. (2016), $11.9 \%$ to ciprofloxacin.

The third primary class, aminoglycosides, showed resistance in $10.78 \%$ of the isolates to amikacin, $22.01 \%$ to gentamicin

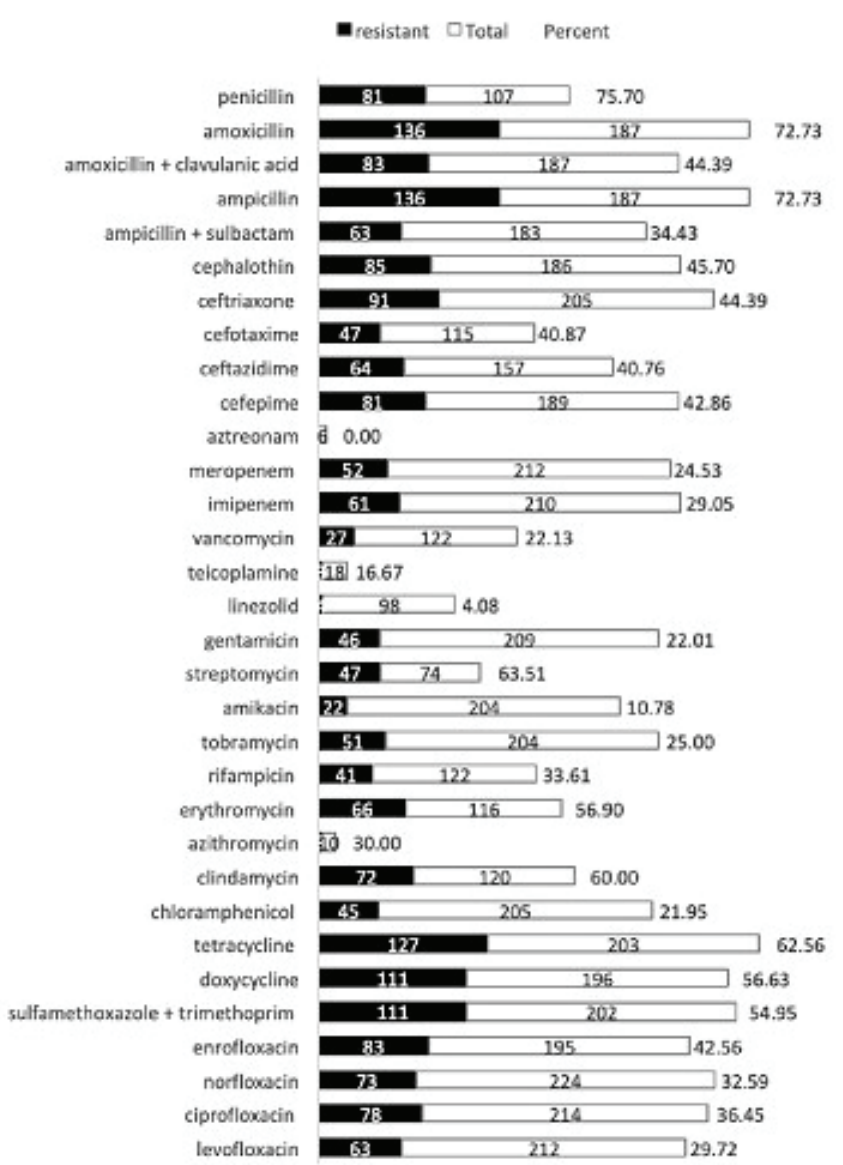

Fig.1. General profile of antimicrobial resistance found in bacteria isolated from infections in small animals in the region of Umuarama/PR, Brazil.

Table 3. Distribution of bacteria found according to the origin of infection in small animals in Umuarama region, Paraná

\begin{tabular}{|c|c|c|c|c|c|c|c|c|c|c|c|}
\hline \multirow[t]{2}{*}{ System } & \multirow[t]{2}{*}{ Infection site } & \multicolumn{2}{|c|}{ Staphylococcus spp. } & \multicolumn{2}{|c|}{$\begin{array}{c}\text { Enterococcus/ } \\
\text { Streptococcus spp. }\end{array}$} & \multicolumn{2}{|c|}{ Enterobacterales } & \multicolumn{2}{|c|}{ NFGNB } & \multicolumn{2}{|c|}{ Total } \\
\hline & & $\mathrm{n}$ & $\%$ & $\mathrm{n}$ & $\%$ & $\mathrm{n}$ & $\%$ & $\mathrm{n}$ & $\%$ & $\mathrm{n}$ & $\%$ \\
\hline \multirow[t]{2}{*}{ Integumentary } & $\begin{array}{c}\text { Skin / } \\
\text { Attachments }\end{array}$ & 47 & 47.96 & 10 & 10.20 & 32 & 32.65 & 9 & 9.18 & 98 & 41.70 \\
\hline & Otological & 40 & 57.97 & 4 & 5.8 & 15 & 21.74 & 10 & 14.49 & 69 & 83.13 \\
\hline \multirow[t]{2}{*}{ Sensory } & Ophthalmic & 4 & 57.14 & 0 & - & 1 & 14.29 & 2 & 28.50 & 7 & 8.43 \\
\hline & Nasal & 3 & 42.86 & 0 & - & 4 & 57.14 & 0 & - & 7 & 8.43 \\
\hline Urinary & Urine & 10 & 31.25 & 6 & 18.75 & 14 & 43.75 & 2 & 6.25 & 32 & 13.60 \\
\hline Female breeder & Vaginal & 1 & 10.00 & 0 & - & 7 & 70.00 & 2 & 20.00 & 10 & 4.26 \\
\hline \multirow[t]{3}{*}{ Others } & Body fluids & 2 & 50.00 & 1 & 25.00 & 1 & 25.00 & 0 & - & 4 & 33.33 \\
\hline & Not identified & 0 & - & 1 & 12.50 & 6 & 75.00 & 1 & 12.50 & 8 & 66.67 \\
\hline & & 107 & 45.53 & 22 & 9.36 & 80 & 34.04 & 26 & 11.06 & 235 & 100.00 \\
\hline
\end{tabular}

NFGNB = Non-fermenting Gram-negative bacilli. 
and $25 \%$ to tobramycin, maintaining similar values between Staphylococcus and enterobacteria. Pseudomonas showed $5.55 \%$ of resistance to amikacin and $17.65 \%$ of resistance to tobramycin. Both Acinetobacter isolates were susceptible to amikacin, and one was resistant to gentamicin. Streptococcus and Enterococcus are intrinsically resistant to aminoglycosides.

Resistance rates vary according to the type of microorganism studied and location. The lowest resistances found in this study for conventional antimicrobial drugs in veterinary medicine were for amikacin, gentamicin, and tobramycin. Unlike Stefanetti et al. (2017) in Italy, with resistance in $43 \%$ of $S$. pseudintermedius isolates for amikacin and 61\% for gentamicin. Scherer et al. (2018) studying S. pseudintermedius in dogs with otitis external in Minas Gerais, Brazil, found $27.3 \%$ of resistance to gentamicin. Kohl et al. (2016) in the state of Santa Catarina, Brazil, detected gentamicin resistance in 33.33\% of Gram-negative and 12\% of Gram-positive. Ishii et al. (2011) detected resistance to amikacin in $32.6 \%$, gentamicin in $36.6 \%$ and tobramycin in $33.3 \%$ of bacterial isolates. Carvalho et al. (2016), studying Escherichia coli from dog feces in Rio de Janeiro, Brazil, detected resistance of $30.9 \%$ to gentamicin. Yadav et al. (2018) found $100 \%$ of isolates of $S$. aureus of canine origin susceptible to gentamicin and amikacin.

The resistance to tetracycline and doxycycline was observed in $62.56 \%$ and $56.63 \%$, respectively, remaining in these proportions in staphylococci and enterobacteria. In enterococci and streptococci, the resistance to tetracycline was $85 \%$ and $73.68 \%$, respectively. Potentiated sulfa resistance was found in $54.95 \%$ of the bacterial isolates tested, where the same patterns of tetracyclines were found in staphylococci and enterobacteria, increasing in enterococci and streptococci $(66.67 \%)$. The resistance to phenicols, represented by chloramphenicol was $21.95 \%$, being $16.04 \%$ in staphylococci, $30.77 \%$ in enterobacteria and $19.05 \%$ in enterococci and streptococci. Intrinsic resistance for these three classes is observed in NFGNB, including pseudomonas and acinetobacter.

Resistance to tetracyclines and potentiated sulfonamides was also found by Stefanetti et al. (2017) with 73\% of resistance to doxycycline and $80 \%$ to sulfamethoxazole-trimethoprim; Scherer et al. (2018) with $61.4 \%$ to tetracycline and $63.6 \%$ to sulfamethoxazole + trimethoprim; and Ishii et al. (2011) with $75.6 \%$ to sulfamethoxazole + trimethoprim. While Silva et al. (2014) detected $4.5 \%$ of resistance to doxycycline and $29.9 \%$ to sulfamethoxazole + trimethoprim and Carvalho et al. (2016), 50\% to tetracycline, $33.3 \%$ to doxycycline and $30.9 \%$ to sulfamethoxazole + trimethoprim. Carvalho et al. (2016), in $E$. coli, found chloramphenicol resistance in $23.8 \%$ of dog isolates.
Drugs considered to be shorter spectrum also showed high resistance, observed in $53.0 \%$ of staphylococci and $90.91 \%$ of enterococci and streptococci to clindamycin; $54.74 \%$ of staphylococci to erythromycin; $30 \%$ of enterococci and streptococci to azithromycin; $25 \%$ of staphylococci and $83.33 \%$ of enterococci and streptococci to rifampicin; and $63.51 \%$ of enterobacteria to streptomycin. The shortest and most modern drugs presented resistance in $25.49 \%$ of staphylococci and $5 \%$ of enterococci and streptococci to vancomycin; $16.67 \%$ of enterococci and streptococci to teicoplanin; and $3.75 \%$ of staphylococci and $5.56 \%$ of enterococci and streptococci to linezolid. Aztreonam, known as the anti-pseudomonas drug, had a $100 \%$ susceptibility in the evaluated pseudomonas.

Because pseudomonas has high intrinsic resistance, a small number of antimicrobials are tested (CLSI 2018). A critical resistance found in these microorganisms is resistance to fluoroquinolones, found in 7 of 19 isolates (36.84\%). Lin et al. (2012) in their study with Pseudomonas isolated from dogs in China found only $14.8 \%$ of resistance to fluoroquinolones, as well as resistance to amikacin (11.1\%), gentamicin and tobramycin (14.8\%), ceftazidime (3.7\%) and imipenem $(0 \%)$, unlike this study which did not detect resistance to ceftazidime, but $16.67 \%$ of resistance to cefepime and imipenem was detected. Low resistance was also found in the present study in pseudomonas for amikacin (5.55\%), gentamicin (22.22\%) and tobramycin $(17.65 \%)$.

High intrinsic resistance is also observed in Acinetobacter (BrCAST, 2019), where both isolates were resistant to all fluoroquinolones tested, one to imipenem and gentamicin and none to amikacin.

According to Jackson et al. (2009), in their study with enterococci isolated from dogs, high resistance was found to chloramphenicol, ciprofloxacin, and gentamicin, unlike the present study which detected high resistance to all cephalosporins, azithromycin, clindamycin, and tetracyclines.

Multidrug resistance, evaluated by the MAR index (Krumperman 1983), showed $64.25 \%$ of bacterial isolates as multidrug-resistant, according to Magiorakos et al. (2012), 68.94\%. When classified, $48.94 \%$ were considered multiresistant (between 0.2 and 0.8 ) and $15.32 \%$ as extensively resistant (above 0.8 ) according to MAR index, according to Magiorakos et al. (2012), 49.79\% were considered multiresistant (between 0.3 and 0.8 ) and 19.15\% extensively resistant (above 0.8). No bacterial isolates were characterized as pan-resistant (all classes and drugs tested resistant), although ten isolates were resistant to all classes, isolated drugs were considered susceptible in these (Table 4).

Table 4. Evaluation of multiresistance in bacteria isolated from infections in small animals in the region of Umuarama/PR, Brazil

\begin{tabular}{|c|c|c|c|c|c|c|c|c|c|c|}
\hline \multirow{2}{*}{ Resistance } & \multicolumn{2}{|c|}{ Staphylococcus spp. } & \multicolumn{2}{|c|}{ Enterococcus/ Streptococcus spp. } & \multicolumn{2}{|c|}{ Enterobacterales } & \multicolumn{2}{|c|}{ NFGNB } & \multicolumn{2}{|c|}{ Total } \\
\hline & MDR & MAR & MDR & MAR & MDR & MAR & MDR & MAR & MDR & MAR \\
\hline$>0.3 />0.2$ & 70 & 64 & 18 & 17 & 61 & 58 & 13 & 12 & 162 & 151 \\
\hline$>0.8$ & 21 & 22 & 2 & 5 & 19 & 9 & 3 & 0 & 45 & 36 \\
\hline MDR & 49 & 42 & 16 & 12 & 42 & 49 & 10 & 12 & 117 & 115 \\
\hline XDR & 21 & 22 & 2 & 5 & 19 & 9 & 3 & 0 & 45 & 36 \\
\hline
\end{tabular}

NFGNB = Non-fermenting Gram-negative bacilli; MDR = multidrug-resistant bacteria, MAR = multiple antibiotic resistance indexing, XDR $=$ extensively drug-resistance bacteria. 


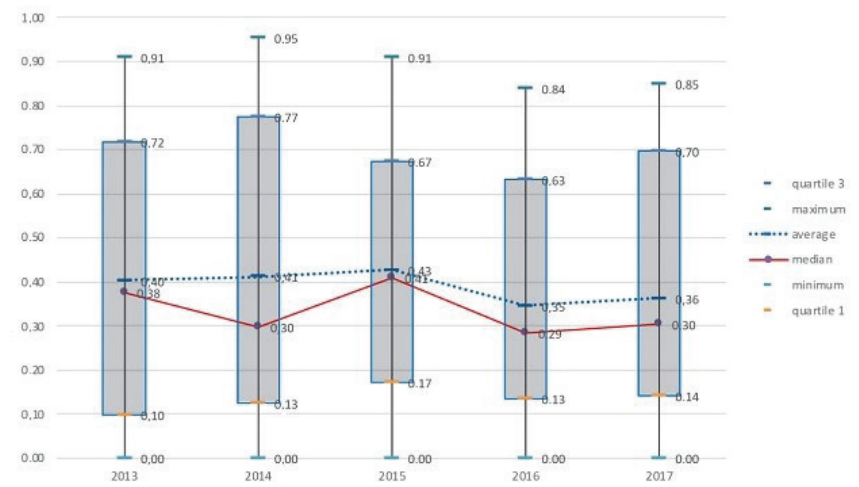

Fig. 2. Boxplot containing the multiple antibiotic resistance indexing (MAR), regardless of the isolated agent, in the respective years studied.

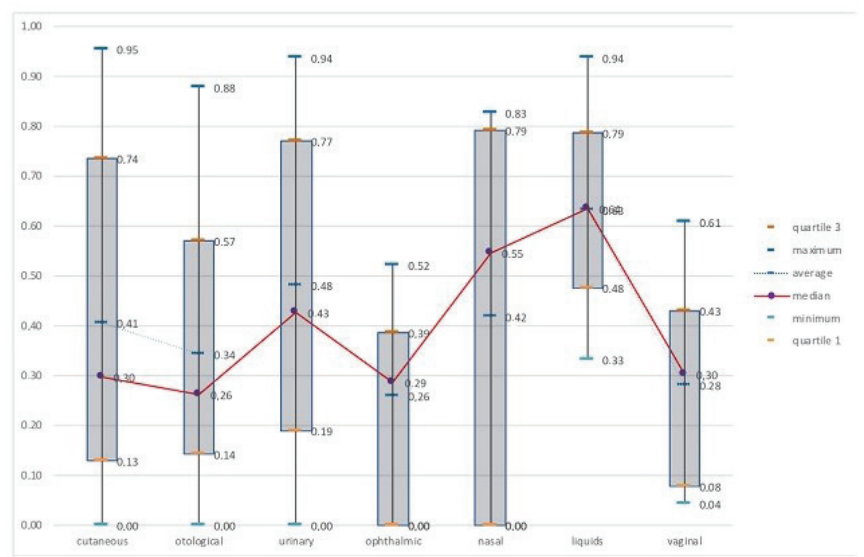

Fig.3. Boxplot containing the multiple antibiotic resistance indexing (MAR), independent of the isolated agent, in the respective infection sites.

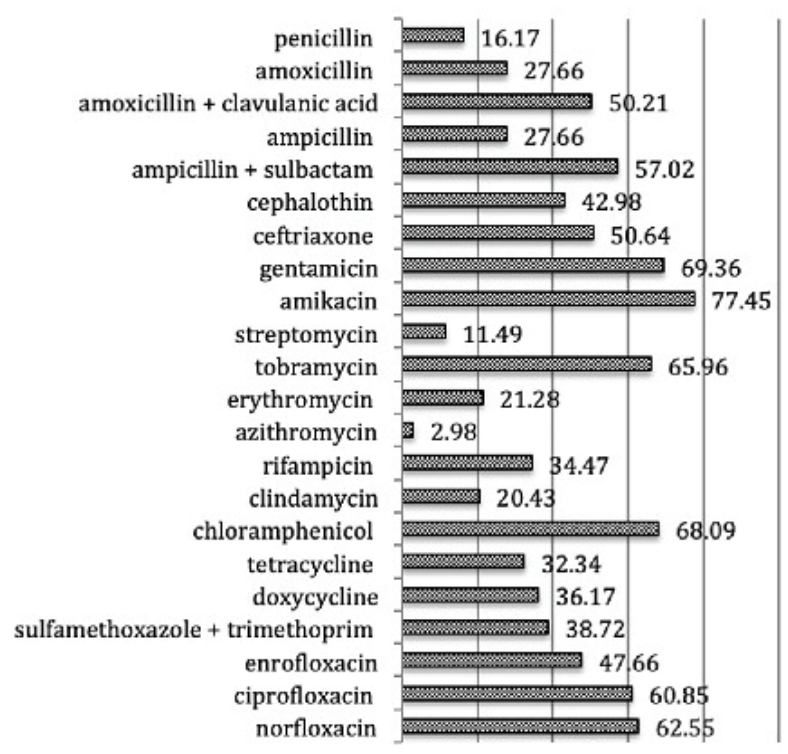

Fig.4. Impact factor of antibiotics used in veterinary medicine of bacteria isolated from infections in small animals in the region of Umuarama/PR, Brazil.
Arias et al. (2013) report a gradual increase in multidrug resistance of antimicrobial agents in veterinary medicine. High rates of multiresistant bacteria were found by Arias et al. (2008) in bacteria isolated from infected and contaminated traumatic animal wounds, with a MAR Index $\geq 0.2$ representing $95 \%$ of isolated bacteria, with a mean of 0.7 . Three isolates presented MAR = 1.0. Sfaciotte et al. (2014) found similar values, where $89.4 \%$ of isolates were considered multiresistant, with a mean MAR index of 0.65 and a maximum of 1.0 . Kohl et al. (2016) detected multiresistant strains in 33.3 to $100 \%$ of the groups evaluated per period, between Gram-positive and -negative bacteria, with MAR averages between 0.2 and 0.52 . Corroborating the study by Arias et al. (2013), who at the Veterinary Hospital of Londrina-Paraná, found high multidrug resistance in all isolates evaluated. All three studies found higher MAR values in Gram-negative bacteria.

Verifying the distribution of the MAR index and evaluating the resistance profile in the period studied (Fig.2), the average curve remains constant from 2013 to 2015, with a low for the following two years. It is also observed that both the average and the median presented values above 0.2 in all evaluated years.

The distribution of the MAR index according to the site of infection (Fig.3) shows superior position measurements for urinary tract infections, respiratory infections represented by nasal samples and body fluids, although the latter two, by low sampling, may not represent the real importance of this resistance.

One of the pillars of prudent antimicrobial therapy is the use of evidence-based antimicrobials (Guardabassi \& Prescott 2015). The prevalence of each microorganism associated with its susceptibility underlies the calculation of the impact factor of each antimicrobial, according to Hall et al. (2013) and Rampacci et al. (2018), considered the most accurate indicator of antimicrobial efficacy, according to which the higher the impact factor, the greater the predicted clinical efficacy. The drugs used in antimicrobial therapy in animals with the highest impact factor (Fig.4) were amikacin, followed by gentamicin, chloramphenicol, tobramycin, for topical use only, norfloxacin and ciprofloxacin. Intermediate results for sulbactam-associated ampicillin, ceftriaxone, clavulanic acid amoxicillin, and enrofloxacin. The worst results were found for azithromycin, streptomycin, and penicillin, where we can mention the short spectrum of these antibiotics.

Ishii et al. (2011) point out the difficulty of the empirical selection of antimicrobial drugs with the emergence of antimicrobial resistance. Knowledge of bacterial resistance profiles in the region is essential so that antibiotic prescriptions are not based on resistance patterns described in the literature that may not reflect the reality of the site, as observed in this study. According to Guardabassi \& Prescott (2015), these studies increase the possibilities of developing infection control practices, specific to each location, making conscious and moderate use of available antibiotics.

\section{CONCLUSIONS}

Staphylococcus spp. represented $45.53 \%$ of bacteria isolated from clinical infections in small animals in the period and placed evaluated, followed by enterobacteria (34.04\%), nonfermenting Gram-negative bacilli (11.06\%) and Streptococcus / Enterococcus (9.36\%). 
According to the number of resistant antimicrobial drugs, $64.26 \%(151 / 235)$ of the isolates were classified as multidrugresistant, being $15.32 \%$ extensively resistant. Considering the resistance to antimicrobial classes, 68.94\% (162/235) of the isolates were considered multiresistant, being $19.15 \%$ extensively resistant. No bacterial isolates were characterized as pan-resistant, but ten bacteria were resistant to all classes tested, with isolated susceptibility to certain drugs.

Resistance to all antimicrobial drugs used in veterinary medicine was found. The lowest resistances associated with the best impact factor values were found for amikacin, gentamicin, chloramphenicol, tobramycin, norfloxacin, and ciprofloxacin. Intermediate results were found for sulbactamassociated ampicillin, ceftriaxone, clavulanic acid amoxicillin, and enrofloxacin.

By evaluating the antimicrobial resistance profiles found at the time and place studied, it can be concluded that there is an increasing in the number of multidrug-resistant agents among domestic animals, which becomes a serious public health risk for all those come into direct or indirect contact with them - including through the environment - especially their tutors and healthcare professionals such as the veterinarian.

It can also be seen that the therapeutic arsenal is becoming smaller and smaller, and there is more difficulty in the empirical selection of drugs to be instituted in clinical treatment. Making it essential to perform bacterial identification tests and their awareness of their sensitivity to a more specific selection of drugs to be used, and educational measures on the conscious use of antibiotics, infection control, and prevention of sitespecific zoonoses need to be instituted for knowledge of health professionals and general access of the population.

Acknowledgements.- The authors are grateful to the "Fundação Araucária de Apoio ao Desenvolvimento Científico e Tecnológico do Estado do Paraná" (001/2016); "Laboratório de Microrganismos de Referência” of "Fundação Oswaldo Cruz" (Fiocruz) for assigning ATCC strains; and Graduate Program in Sustainable Production and Animal Health, "Universidade Estadual de Maringá” (UEM).

Conflict of interest statement.- The authors have no competing interests.

\section{REFERENCES}

Acar J.F., Moulin G., Page S.W. \& Pastoret P.P. 2012. Antimicrobial resistance in animal and public health: introduction and classification of antimicrobial agents. Rev. Sci. Tech. Off. Int. Epiz. 31(1):15-21. <https://dx.doi.org/10.20506/ rst.31.1.2093><PMid:22849264>

Adeolu M., Alnajar S., Naushad S. \& Gupta R.S. 2016. Genome-based phylogeny and taxonomy of the 'Enterobacterales': proposal for Enterobacterales ord. nov. divided into the families Enterobacteriaceae, Erwiniaceae fam. nov., Pectobacteriaceae fam. nov., Yersiniaceae fam. nov., Hafniaceae fam. nov., Morganellaceae fam. nov., and Budviciaceae fam. nov. Int. J. Syst. Evol. Microbiol. 66:5575-5599. <https://dx.doi.org/10.1099/ijsem.0.001485> $<$ PMid:27620848>

Aidara-Kane A. 2012. Containment of antimicrobial resistance due to use of antimicrobial agents in animals intended for food: WHO perspective. Rev. Sci. Tech. Off. Int. Epiz. 31(1):277-287. <https://dx.doi.org/10.20506/ rst.31.1.2115><PMid:22849282>

Anvisa 2017. Diretriz nacional para elaboração de programa de gerenciamento do uso de antimicrobianos em serviços de saúde. Agência Nacional de Vigilância Sanitária, Brasília, DF. 90p.

Arias M.V.B., Aiello G., Battaglia L.A. \& Freitas J.C. 2013. Estudo da ocorrência de infecção hospitalar em cães e gatos em um centro cirúrgico veterinário universitário. Pesq. Vet. Bras. 33(6):771-779. <https://dx.doi.org/10.1590/ S0100-736X2013000600014>

Arias M.V.B., Battaglia L.A., Aiello G., Carvalho T.T. \& Freitas J.C. 2008. Identificação da suscetibilidade antimicrobiana de bactérias isoladas de cães e gatos com feridas traumáticas contaminadas e infectadas. Semina, Ciênc. Agrárias 29(4):861-874. <https://dx.doi.org/10.5433/16790359.2008v29n4p861>

Bardiau M., Yamazaki K., Ote I., Misawa N. \& Mainil J.G. 2013. Characterization of methicillin-resistant Staphylococcus pseudintermedius isolated from dogs and cats. Microbiol. Immunol. 57(7):496-501. <https://dx.doi. org/10.1111/1348-0421.12059><PMid:23607810>

Barie P.S. 2012. Multidrug-resistant organisms and antibiotic management. Surg. Clin. N. Am. 92(2):345-391. <https://dx.doi.org/10.1016/j. suc.2012.01.015><PMid:22414417>

BrCAST 2019. Tabela de pontos de corte para interpretação de CIMs e diâmetros de halos. Brazilian Commitee on Antimicrobial Suscetibilitty Testing, s.l. 70p.

Carvalho A.C., Barbosa A.V., Arais L.R., Ribeiro P.F., Carneiro V.C. \& Cerqueira A.M.F. 2016. Resistance patterns, ESBL genes, and genetic relatedness of Escherichia coli from dogs and owners. Braz. J. Microbiol. 47(1):150-158. <https://dx.doi.org/10.1016/j.bjm.2015.11.005>

CLSI 2008. Performance Standards for Antimicrobial Disk and Dilution Susceptibility Tests for Bacteria Isolated from Animals. CLSI document M31-A3, Approved Standard, 3rd ed., Clinical and Laboratory Standards Institute, Wayne, PA. 103p.

CLSI 2013. Performance Standards for Antimicrobial Disk and Dilution Susceptibility Tests for Bacteria Isolated from Animals. CLSI document VET01-A4, Approved Standard, 4th ed., Clinical and Laboratory Standards Institute, Wayne, PA. 81p.

CLSI 2018. Performance Standards for Antimicrobial Disk and Dilution Susceptibility Tests for Bacteria Isolated From Animals. CLSI standard VET01, 5th ed., Clinical and Laboratory Standards Institute, Wayne, PA. 156p.

Fernandes M.R., Sellera F.P., Moura Q., Carvalho M.P.N., Rosato P.N., Cerdeira L. \& Lincopan N. 2018. Zooanthroponotic transmission of drug-resistant Pseudomonas aeruginosa, Brazil. Emerg. Infect. Dis. 24(6):1160-1162. <https://dx.doi.org/ 10.3201/eid2406.180335> <PMid:29774849>

Giguère S. 2013. Antimicrobial drug action and interaction: an introduction, p.3-7. In Giguère S., Prescott J.F. \& Dowling P.M. (Eds), Antimicrobial Therapy in Veterinary Medicine. 5th ed. John Wiley and Sons, Hoboken, New Jersey.

Guardabassi L. \& Prescott J.F. 2015. Antimicrobial stewardship in small animal veterinary practice. Vet. Clin. N. Am., Small Anim. Pract. 45(2):361-376. <https://dx.doi.org/10.1016/j.cvsm.2014.11.005> <PMid:25721619>

Guardabassi L., Jensen L.B. \& Kruse H. 2010. Guia de Antimicrobianos em Veterinária. Artmed, Porto Alegre. 268p.

Haenni M., De Moraes N.A., Châtre P., Médaille C., Moodley A. \& Madec J.Y. 2014. Characterisation of clinical canine meticillin-resistant and meticillinsusceptible Staphylococcus pseudintermedius in France. J. Glob. Antimicrob. Resist. 2(2):119-123. <https://dx.doi.org/10.1016/j.jgar.2014.02.002> <PMid:27873590>

Hall J.L., Holmes M.A. \& Baines S.J. 2013. Prevalence and antimicrobial resistance of canine urinary tract pathogens. Vet. Rec. 173(22):549. <https://dx.doi. org/10.1136/vr.101482><PMid:24158327>

Ishii J.B., Freitas J.C. \& Arias M.V.B. 2011. Resistência de bactérias isoladas de cães e gatos no Hospital Veterinário da Universidade Estadual de Londrina (2008-2009). Pesq. Vet. Bras. 31(6):533-537. <https://dx.doi. org/10.1590/S0100-736X2011000600013>

Jackson C.R., Fedorka-Cray P.J., Davis J.A., Barrett J.B. \& Frye J.G. 2009. Prevalence, species distribution and antimicrobial resistance of enterococci isolated from dogs and cats in the United States. J. Appl. Microbiol. 107(4):1269-1278. <https://dx.doi.org/10.1111/j.1365-2672.2009.04310.X><PMid:19486402> 
Joseph J. \& Rodvold K.A. 2008. The role of carbapenems in the treatment of severe nosocomial respiratory tract infections. Expert Opin. Pharmacother. 9(4):561-575. <https://dx.doi.org/10.1517/14656566.9.4.561> <PMid:18312158>

Kohl T., Pontarolo G.H. \& Pedrassani D. 2016. Resistência antimicrobiana de bactérias isoladas de amostras de animais atendidos em hospital veterinário. Saúde Meio Ambiente, Revta Interdisciplinar 5(2):115-127. $<$ https://dx.doi.org/10.24302/sma.v5i2.1197>

Krumperman P.H. 1983. Multiple antibiotic resistance indexing of Escherichia coli to identify high-risk source of fecal contamination of foods. Appl. Environ. Microbiol. 46(1):165-170. <https://dx.doi.org/10.1128/AEM.46.1.165170.1983><PMid:6351743>

Lin D., Foley S.L., Qi Y., Han J., Ji C., Li R, Wu C., Shen J. \& Wang Y. 2012. Characterization of antimicrobial resistance of Pseudomonas aeruginosa isolated from canine infections. J. Appl. Microbiol. 113(1):16-23. <https://dx.doi.org/10.1111/j.1365-2672.2012.05304.x><PMid:22487022>

Magiorakos A.P., Srinivasan A., Carey R.B., Carmeli Y., Falagas M.E., Giske C.G., Harbarth S., Hindler J.F., Kahlmeter G., Olsson-Liljequist B., Paterson D.L., rice L.B., Stelling J., Struelens M.J., Vatopoulos A., Weber J.T. \& Monnet D.L. 2012. Multidrug-resistant, extensively drug-resistant and pandrugresistant bacteria: an international expert proposal for interim standard definitions for acquired resistance. Clin. Microbiol. Infect. 18(3):268-281. <https://dx.doi.org/10.1111/j.1469-0691.2011.03570.x><PMid:21793988>

Messenger A.M., Barnes A.N. \& Gray G.C. 2014. Reverse zoonotic disease transmission (zooanthroponosis): a systematic review of seldomdocumented human biological threats to animals. PLoS One 9(2):e89055. <https://dx.doi.org/10.1371/journal.pone.0089055><PMid:24586500>

Molina F., Alí A., Beltrán N., Camargo R., Castro L., Fonseca N., Gil B., Gómez U., Mercado M., Solarte M., Oñate J., Osorio J., Pinillos O., Urbina Z., Valderrama S. \& Villarreal A. 2012. DE-ESCALAR: una estrategia terapéutica en la Unidad de Cuidado Intensivo. Acta Colomb. Cuid. Intens. 12(3):163-169.

Murphy P., Reid-Smith R.J., Boerlin P., Weese J.S., Prescott J.F., Janecko N. \& Mcewen S.A. 2012. Out-patient antimicrobial drug use in dogs and cats for new disease events from community companion animal practices in Ontario. Can. Vet. J. 53(3):291-298. <PMid:22942447>

Pereira A.L. \& Pita J.L. 2005. Alexander Fleming (1881-1955): da descoberta da penicilina (1928) ao Prémio Nobel (1945). Revta Facul. Letras, Hist., Porto 6:129-151.

Pereira I.A., Soares L.C., Coelho S.M.O., Pribul B.R. \& Souza M.M.S. 2009. Suscetibilidade à azitromicina de isolados bacterianos de processos infecciosos em cães e gatos. Pesq. Vet. Bras. 29(2):153-156. <https://dx.doi.org/10.1590/S0100-736X2009000200012>

Prescot J.T. 2013. Beta-lactam antibiotics: penam penicillins. p.135-152. In Giguère S., Prescott J.F. \& Dowling P.M. (Eds), Antimicrobial Therapy in Veterinary Medicine. 5th ed. John Wiley and Sons, Hoboken, New Jersey.

Rampacci E., Bottinelli M., Stefanetti V., Hyatt D.R., Sgariglia E., Coletti M. \& Passamonti F. 2018. Antimicrobial susceptibility survey on bacterial agentes of canine and feline urinary tract infections: weight of the empirical treatment. J. Glob. Antimicrob. Resist. 13:192-196. <https://dx.doi.org/10.1016/j.jgar.2018.01.011> <PMid:29408407>

Scherer C.B., Botoni L.S., Coura F.M., Silva R.O., Santos R.D., Heinemann M.B. \& Costa-Val A.P. 2018. Frequency and antimicrobial susceptibility of Staphylococcus pseudintermedius in dogs with otitis externa. Ciência Rural 48(4):e20170738. <https://dx.doi.org/10.1590/0103-8478cr20170738>

Sfaciotte R.A.P., Coronel L.G., Snak A., Bordin J.T., Wildemann P., Melo F.D., Vignoto V.K.C., Ferraz S.M., Wosiacki S.R. \& Osaki S.C. 2017. Antimicrobial resistance phenotypic profile of isolates from clinical infections in dogs. Acta Scient. Vet. 45:1485. <https://dx.doi.org/10.22456/1679-9216.80501>

Sfaciotte R.A.P., Vignoto V.K.C. \& Wosiacki S.R. 2014. Perfil de resistência antimicrobiana de isolados bacterianos de afecções clínicas do Hospital Veterinário da Universidade Estadual de Maringá. Revta Ciênc. Vet. Saúde Públ. 1(1):29-38. <https://dx.doi.org/10.4025/revcivet.v1i1.23281>

Silva A.P., Schmidt C., Vargas A.C., Maboni G., Rampelotto C., Schwab M.L., Escobar T.P. \& Amaral A.S. 2014. Suscetibilidade antimicrobiana de Staphylococcus spp. isolados de cães com pioderma superficial. Pesq. Vet. Bras. 34(4):355361. <https://dx.doi.org/10.1590/S0100-736X2014000400010>

Stefanetti V., Bietta A., Pascucci L., Marenzoni M.L., Coletti M., Franciosini M.P., Passamonti F. \& Proietti P.C. 2017. Indagine su antibiotico-resistenza e formazione di biofilm in ceppi di Staphylococcus pseudintermedius isolati da piodermiti canine. Vet. Ital. 53(4):289-296. <https://dx.doi. org/10.12834/VetIt.465.2275.6>

Ventola C.L. 2015. The antibiotic resistance crisis: part 1: causes and threat. PT 40(4):277-283. <PMid:25859123>

WHO 2019. Critically important antimicrobials for human medicine. 6th ed. World Health Organization, Geneva. 45p.

Yadav R., Kumar A., Singh V.K., Jayshree \& Yadav S.K. 2018. Prevalence and antibiotyping of Staphylococcus aureus and methicillin-resistant $S$. aureus (MRSA) in domestic animals in India. J. Glob. Antimicrob. Resist. 15:222225. <https://dx.doi.org/10.1016/j.jgar.2018.08.001><PMid:30092364> 